"relative climatic productivity", which assigns an index of 100 to the Soviet Union south of latitude $60^{\circ}$, Hungary scores 139 , second only to Bulgaria with 145 , and agricultural products, especially fruit and vegetables, account for some 30 per cent of Hungary's export earnings.

The goal of relating agriculture more closely to ecology was accepted in the fiveyear plan approved last year. The Hungarian economy has, however, come a long way from the central planning of the post-war Rakosci regime which, in an attempt to make the country selfsufficient, ordered certain collective farms to grow cotton and citrus fruits - with predictably poor results. Since the 1968 economic reform, the managements of the various collective farms have complete autonomy in deciding what they should grow. The only constraints are now those imposed by market prices and government incentives.

Often the consequences have been nonsensical. In the great sugar-beet affair of the mid-1970s, farmers applied more fertilizer than recommended and produced gigantic beet with no increase in sugar content. (Bonuses are now related to sugar yield, not gross weight.) In a more recent scandal, farms have obtained land improvement grants for top-soil dressing and then applied the soil to areas which were already of fairly high quality. This produced money for the farms, and excellent statistics for the soil improvement service - but a net loss to the economy.

The next step towards ecologically orientated agriculture will depend on the working out of suitable incentives for collective farms - free, it is hoped, from the loopholes and misunderstandings of the past.

Vera Rich

\section{Direct satellite broadcasting More TV ahead}

Britain could start direct broadcasting by satellite in the mid-1980s. That is the government's response to the report of a Home Office study commissioned a year ago and published last week. The government favours a modest start in about 1986 beginning with two television channels and possibly some information services.

No change in the way broadcasting is controlled is, however, proposed, nor will the British government, unlike its French and German counterparts, help finance the venture. It hopes that British industry and the broadcasting authorities will be able to raise the money, estimated by the report to be $£ 75-£ 160$ million of capital to establish a system, depending on the type of satellite and the number of channels chosen. Throughout a 10-year period, the annual cost of operating a channel, including original capital costs, is estimated at f10-16 million. In addition, the broadcasting authorities would need to spend between $£ 10$ and $£ 100$ million a year to run the service for 50 hours a week.

The Home Office study was stimulated by the fear that delay could put British industry at a disadvantage in the supply of equipment to what is expected to be a rapidly growing world market. The Home Office also had to work out a way of using the allocation in 1977 of five television channels from geostationary satellites.

There are two possible systems to choose from - a modified version of the European Communications Satellite and a satellite based on L-sat, the prototype of the second generation of telecommunications satellites due for approval by the European Space Agency next month. Signals could be beamed direct to individual 2-3-m dishes or to larger community antennas. Control of programmes would remain with the British Broadcasting Corporation (BBC) and Independent Broadcasting Authority (IBA), which control all British broadcasting through terrestrial systems, although coverage would extend to neighbouring countries.

The investigation uncovered a mixed response to direct broadcasting. The aerospace and electronics manufacturers are the most enthusiastic. The BBC is also keen, believing that it could use two channels - one to transmit repeats of programmes already shown on terrestrial channels and paid for from the standard television licence fee, and the other to transmit new special programmes, paid for by subscription. But the IBA, grappling with the introduction of breakfast television and a fourth television channel, does not think there will be a market before 1990 .

The technical problems are less forbidding than the financial. The broadcasting authorities, which do not have $£ 75-£ 160$ million to invest, would prefer to lease channels from an operator. Private industry, especially the newly-formed Satellite Broadcasting Company Limited, has expressed some interest in launching a satellite and operating it as a common carrier, but industry's willingness to invest will depend on its confidence that a market can be found.

The option of using L-sat to test the British market has been preempted by the Italian broadcasting authorities, which are planning to run an experimental project.

Elsewhere in Europe, France and Germany are planning to take up their allocation of five channels by means of joint ventures. Two of the French channels will be used for broadcasting signals now transmitted terrestrially. The prospect that a third channel might be leased to Luxembourg has faded, while plans for an internationally financed Swiss satellite, aimed at providing commercial television programmes for the whole of Europe, have been set back by the rules on foreign investment in Switzerland. Similarly, the Scandinavian plan for a regional broadcasting service by satellite is in limbo.

Judy Redfearn

\section{Cooling sackcloth}

\section{New Delhi}

This year Indians are beating the summer heat by installing a novel airconditioner on the terraces of homes and offices. They spread a number of empty, used gunny bags (sack made of jute) over the terrace and keep them soaked with water round the clock with the help of sprayers like those used on lawns. This simple system works like an airconditioner. The Sun's heat evaporates the water instead of warming up the roof, and the process of evaporation cools the roof. In other words, the water-soaked gunny bags reverse the heat flow - and the heat from the house is thrown outside through the roof instead of the other way.

A fall of as much as $10^{\circ} \mathrm{C}$ in indoor temperatures has been observed during day times with this technique. Sleeping conditions at night are much better as the ceiling fans, a common fixture in most homes, throw out cold air because the roof is even cooler than the floor.

The "gunny bag airconditioner" has been developed by the Central Building Research Institute (CBRI), who say it is a cheap alternative to the desert coolers and airconditioners that only a few Indians can afford, and which consume electricity that is in short supply. The cost of installing the system per square metre of roof surface is 5.50 ruppees $(\mathfrak{£ 0 . 3 0 )}$ ) and the water requirement is 9 litres per day.

CBRI started experimenting with its technique on its own buildings at the Roorkee campus. Results of these experiments, carried out during three successive summers, were so good that several factories and offices became interested. The system was installed on a 1,650 square metre roof of the fourstorey building of Bharat Heavy Electricals Ltd in Hardwar. After the gunny bag treatment, the roof temperature of the building fell from $45^{\circ} \mathrm{C}$ to $28^{\circ} \mathrm{C}$ and indoor temperature from $39^{\circ} \mathrm{C}$ to $30^{\circ} \mathrm{C}$. According to CBRI scientists S. P. Jain and Vinod Kumar, "not only the top floor but also rooms in the down floor were cooled as a result of constant working of the system'".

CBRI engineers say that passive cooling by roof surface evaporation is suitable not only for India but for all developing countries in the tropics where artificial airconditioning is not within the reach of common man.

So far the roof surface evaporative cooling system has proved successful only for buildings with flat roofs. Attempts to use the system in roofs that are not flat are under way, and there are plans to develop inorganic water retentive materials as a substitute for gunny bags, which need replacement every three years or so.

K.S. Jayaraman 